\title{
CORRECTION
}

\section{Correction to: Clinical Performance of Samfilcon A Contact Lenses in Intensive Digital Device Users: A Multicenter, Prospective Clinical Study}

\author{
Ömür Ö. Uçakhan • Emrullah Taşındı • Ebru Toker • Ferda Çiftçi • \\ Sevda Aydın Kurna · Mutlu Acar · Ferah Özçelik · Ali Rıza Cenk Çelebi • \\ Hatice Elvin Yıldız • Yonca Aydın Akova • Emine Sibel Öncü • \\ Zeynep Özbek · Zerrin Tuncer · Sibel Kocabeyoğlu • Burak Şeker • \\ Deniz Kaya · Maxime Barakat \\ Published online: October 22, 2021 \\ (C) The Author(s) 2021 \\ Correction to: Ophthalmol Ther \\ https://doi.org/10.1007/s40123-021-00389-4
}

The original article can be found online at https://doi. org/10.1007/s40123-021-00389-4.

Ö. Ö. Uçakhan

Department of Ophthalmology, Ankara University

School of Medicine, Ankara, Turkey

E. Taşınd 1

Department of Ophthalmology, İstanbul Okan

University Faculty of Medicine, Istanbul, Turkey

E. Toker

Department of Ophthalmology, Marmara University Pendik Training and Research Hospital, Istanbul,

Turkey

F. Çiftçi

Department of Ophthalmology, Batıgöz Altunizade Hospital, Istanbul, Turkey

\section{S. A. Kurna}

Department of Ophthalmology, Fatih Sultan

Mehmet Training and Research Hospital, Istanbul,

Turkey

M. Acar

Department of Ophthalmology, Dışkapı Yıldırım Beyazit Training and Research Hospital, Ankara, Turkey

\section{F. Özçelik}

Department of Ophthalmology, Prof Dr Reşat Belger Beyoğlu Training and Research Hospital, Istanbul, Turkey

\section{A. R. C. Çelebi}

Department of Ophthalmology, Acibadem Atakent Hospital, Istanbul, Turkey

\section{H. E. Yildiz}

Department of Ophthalmology, Haydarpaşa

Numune Training and Research Hospital, Istanbul, Turkey

\section{Y. A. Akova}

Department of Ophthalmology, Bayındır Kavaklidere Hospital, Ankara, Turkey

\section{E. S. Öncü}

Department of Ophthalmology, Birinci Eye Hospital, Istanbul, Turkey

\section{Z. Özbek}

Department of Ophthalmology, 9 Eylül University Hospital, Izmir, Turkey 
Figure 3 in the original version of this article has been replaced, the figure should have appeared as shown below.

The original article has been corrected.

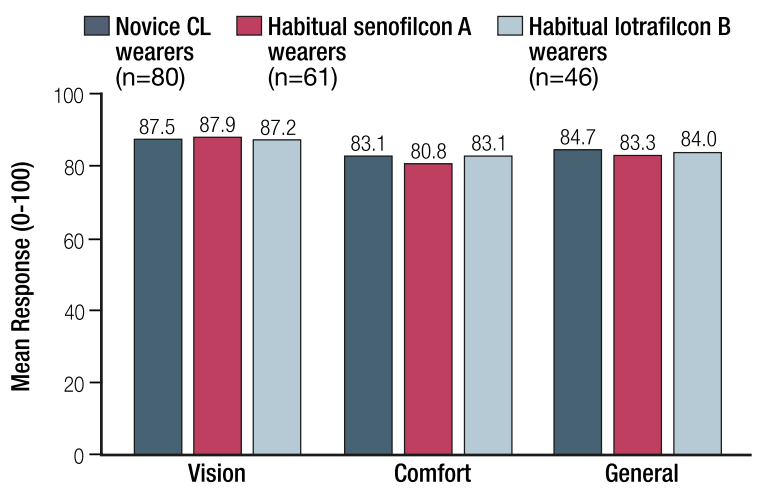

Fig. 3 Patient satisfaction with samfilcon A lenses: comfort, visual quality and in general (4-week assessment). $C L$ contact lens. Likert Scale (0-100) 100-81: excellent; 80-61: very good; 60-41: good; 40-21: fair; 20-0: poor

\section{OPEN ACCESS}

This article is licensed under a Creative Commons Attribution-NonCommercial 4.0 International License, which permits any noncommercial use, sharing, adaptation, distribution and reproduction in any medium or format, as long as you give appropriate credit to the original author(s) and the source, provide a link to the Creative Commons licence, and indicate if changes were made. The images or other third party material in this article are included in the article's Creative Commons licence, unless indicated otherwise in a credit line to the material. If material is not included in the article's Creative Commons licence and your intended use is not permitted by statutory regulation or exceeds the permitted use, you will need to obtain permission directly from the copyright holder. To view a copy of this licence, visit http://creativecommons.org/licenses/bync/4.0/.

Z. Tuncer

Department of Ophthalmology, Göz Vakf1

Bayrampaşa Eye Hospital, Istanbul, Turkey

S. Kocabeyoğlu

Department of Ophthalmology, Hacettepe University

Faculty of Medicine, Ankara, Turkey

B. Şeker $(\bowtie) \cdot$ D. Kaya

Bausch + Lomb, Istanbul, Turkey

e-mail: burak.seker@bausch.com

M. Barakat

Bausch Health, Laval, QC, Canada 